and can only be tackled after an adequate idea of the nature of a society has been gained. This is in the first place a task for social science, since science alone has sufficient authority to get its conclusions adopted universally as a basis for action.

\section{Science and University Teaching}

AN article by Dr. W. H. George on "Science and University Teaching" in the New University of November, emphasizing the value of the widespread use of scientific methods in dealing with the social problems of to-day, points out that an education which includes one or more sciences does not necessarily foster scientific action. Even a knowledge of science up to university degree standard does not necessarily guarantee ability to think or act scientifically within the scope of the sciences studied. While, however, teaching is the best way of promoting the use of the scientific method, Dr. George points out that, in general, science but no scientific method is taught to science students and that scientific method, but no science, is taught to a small proportion of arts students and this teaching is separated from that of the student's main subject of study.

\section{National Forest Park near Snowdon}

A commixteE was appointed by the Forestry Commissioners on March 31 last to advise as to the steps which might be taken to form a national forest park on their properties in the vicinity of Snowdonia. It has now issued its report on the "National Forest Park Committee" (H.M. Stationery Office, 1937). The Forestry Commissioners had expressed an intention of designating areas, such as the one here under consideration, 'National Forest Parks'. It is pointed out that this type of park has no affinity with the 'National Park' as described in the report of the National Park Committee. The area here in question is the Gwydyr Forest of about 18,000 acres. The Forest forms a fringe of the wild and open mountain land culminating with the Snowdon range with its large stretches of foothills and rough grass, heather and rock-strewn spaces. The central Snowdon region is mostly in private ownership. The land in Gwydyr Forest which has been, or will be, planted by the Forestry Commissioners comprises about three. quarters of the area and forms the lower slopes on the east and south-east of the Snowdon range, in which group of mountains is included the Glyders and Carnedd mountains. There are numerous roads, tracks and footpaths, many of which afford delightful walks, climbs and views. The district includes some of the finest mountain scenery in North Wales and attracts a very large number of holiday-makers in the summer. The larger part of the Forest is held by the Commissioners on long leases subject to certain reservations. Local hostels exist, and certain other facilities in this respect and camping facilities are recommended, it being suggested that Government be asked to provide funds for the Commissioners' use in these developments. Such funds should surely be obtainable from the region which will benefit by the provision of this national forest park.
Acquisitions at the British Museum (Natural History)

Among the specimens presented to the Department of Mineralogy of the British Museum (Natural History) is a collection of about three hundred rock and mineral specimens, made by Mr. H. St. J. B. Philby, between Mecca and Mukalla, during his last journey of exploration through West and South. West Arabia. The collection is not only of academic interest. There is evidence of the presence of oil in the richly bituminous limestones and oil-soaked shales outcropping in the neighbourhood of Shabwa, and farther north, near Jizan, Mr. Philby collected specimens of hæmatite, an important iron-ore. This mineral is also present in several quartz-reefs, of which he brought back samples. By his careful and complete field-records of each occurring type, $\mathrm{Mr}$. Philby has brought to light a number of salient features in the geological structure of a region previously unknown to Europeans, and has made it possible to prepare an approximate geological map of the region through which he travelled.

\section{Vital Statistics in Great Britain}

ACCORDING to a return published by the RegistrarGeneral, the birth-rate in England and Wales during the year 1937 is provisionally estimated at 14.9 live births per thousand of the population, and the crude death-rate at 12.4 deaths per thousand of the population. The number of deaths of children under one year, per 1000 live births, was 58. The birthrate for 1937 is 0.1 above that for $1936,0.2$ above that for 1935 and 0.5 above that for 1933 the lowest on record. The crude death-rate is the highest recorded since 1929 and is 0.3 above that of 1936, an increase which is largely associated with the heavy influenza mortality of the first quarter of the year. The infant mortality is 1 below that of 1936 , and only 1 above that of 1935-the lowest recorded.

\section{Rheumatic Fever as a Protozoal Disease}

Dr. G. Arbour Stephens, 61 Walter Road, Swansea, referring to a recent Colonial Office Medical Report on the Falkland Islands, states that although the weather there is described as very damp and "permanent October" weather, and although the houses are damp, the soil acid, the food so poor that the school children wear dentures, and septic tonsillitis (due to Streptococcus) is so common, nevertheless rheumatic fever does not occur. This, he claims, supports the view that rheumatic fever is due to a protozoon (something like the malarial parasite), for the necessary insect carriers, such as harvest bugs, midges and fleas do not exist on the Islands.

\section{Current Titles}

WE have received the first part of a new monthly journal, Current Titles, published by Engineering Journals, 928 Broadway, New York, the subscription being 3 dollars yearly (4 dollars outside the United States). The journal gives the tables of contents of a large number of scientific, technical and engineering journals in English. We note that these include 